\title{
The chemical composition and potential nutritive value of the foliage of four subtropical tree species in southern Africa for ruminants
}

\author{
M.S. Lukhele and J.B.J. van Ryssen ${ }^{\#}$ \\ Department of Animal \& Wildlife Sciences, University of Pretoria, Pretoria 0002, South Africa
}

\begin{abstract}
The foliage of three Combretum species, C. apiculatum, C. molle and C. zeyheri, as well as that of Colophospermum mopane was collected over a period of two years. The chemical composition, in vitro organic matter digestibility (IVOMD) and the rumen degradability of dry matter (DM) and nitrogen (N) were determined on these samples. Mean values for crude protein (CP) concentration varied from $92 \mathrm{~g} / \mathrm{kg} \mathrm{DM}$ for C. molle to $141 \mathrm{mg} / \mathrm{kg} \mathrm{DM}$ for C. mopane, the neutral detergent fibre concentration from $323 \mathrm{~g} / \mathrm{kg}$ DM for $C$. apiculatum to $392 \mathrm{~g} / \mathrm{kg} \mathrm{DM}$ for $C$. molle and that of acid detergent fibre from $247 \mathrm{~g} / \mathrm{kg} \mathrm{DM}$ for $C$. apiculatum to $355 \mathrm{~g} / \mathrm{kg}$ DM for C. molle. The calcium (Ca) concentration in the foliage was high (8-16 g/ $\mathrm{kg}$ $\mathrm{DM}$ ) compared to the phosphorus (P) concentrations of between $0.8-2.1 \mathrm{~g} / \mathrm{kg} \mathrm{DM}$, resulting in an average $\mathrm{Ca}: \mathrm{P}$ ratio of $9.3: 1$. The foliage contained relatively low levels of sodium $(\mathrm{Na}), 0.041 \mathrm{~g} / \mathrm{kg} \mathrm{DM}$, based on beef cattle standards. The IVOMD ranged from $53 \%$ for $C$. mopane to $64 \%$ C. apiculatum and the rumen degradability of DM from $78 \%$ for $C$. molle to $94 \%$ for $C$. apiculatum. The DM degradability was substantially higher than that of nitrogen, which varied between $47 \%$ for $C$. apiculatum and $60 \%$ for $C$. zeyheri. It was concluded that the foliage tested would not be suitable sources of $\mathrm{N}$ to supplement protein deficiencies in low quality herbage. Furthermore, browsers would require additional sources of $\mathrm{P}$ and Na to avoid deficiencies in these elements.
\end{abstract}

Keywords: Leaves, Combretum species, mopane, ruminal degradability, in vitro digestibility, browse

${ }^{\#}$ Corresponding author. E-mail: jvryssen@postino.up.ac.za

\section{Introduction}

The potential of foliage from fodder trees and shrubs in herbivore nutrition has been investigated in many recent studies (Topps, 1992; Degen et al., 1997; Sawe et al., 1998; El hassan et al., 2000). The plants studied, included multipurpose trees, forage legumes, shrubs and forbs. The value of these plants in animal nutrition is associated with features such as abundance, accessibility, protein content and quality in terms of available energy, minerals and vitamins (Kibria et al., 1994; Ramírez, 1998). The attention is focused on trees in terms of their utilization as browse for both livestock and game, but also in feeding strategies such as chopping and feeding them as part of the diet to livestock, or during periods of feed shortage (Topps, 1992; Kibria et al., 1994). Foliage is claimed to have a great potential as protein supplements to graminaceous fodder and crop by-products containing low protein and fermentable energy levels (El hassan et al., 2000). Larbi et al. (1998) emphasised that an important objective in the evaluation is also to identify tree species with a potential to be introduced in integrated crop and livestock agroforestry systems.

These forages are important for animal production owing to their potentially good nutritive value. Their deep root systems take up minerals and access ground water during periods of water scarcity or when growing in poor topsoils (Topps, 1992). Many trees are evergreen or tend to have foliage longer into the dry season than grasses. Consequently, the chemical composition of the foliage of trees tends to vary less during the year than that of tropical grasses. Species in the Acacia and Combretum families have been identified as vital food sources for game, the giraffe in particular (Owen-Smith et al., 1983; Sauer, 1983). However, a major limitation in the utilisation of foliage as feedstuff is the presence of anti-nutrient components such as tannins in the leaves of many tree species (El hassan et al., 2000).

According to Ramírez (1998) there is a need for more research into ways of managing browse to balance forage quality and quantity. The present study was undertaken to assess the potential nutritional value of the foliage of selected tree species found in the northern region of South Africa.

\section{Materials and Methods}

Foliage of the following tree species, Combretum apiculatum (red bushwillow), Combretum molle (velvet bushwillow), Combretum zeyheri (large-fruited bushwillow) and Colophospermum mopane (mopane) was collected over a period of two years at different sites in and north of Pretoria in the Gauteng and 
Limpopo provinces of South Africa. The samples were collected from the trees throughout all four seasons. Green leaves plus their petiole were picked randomly by hand from different specimens per species at a site, and pooled. A sample of approximately $500 \mathrm{~g}$ dry matter (DM) was put in a paper bag and taken to the laboratory for preparation. After collection the samples were divided into two aliquots. One aliquot was washed by agitation in distilled water to establish the effect of dust contamination on the mineral concentration in the green leaves. Both aliquots were freeze-dried and milled. Each sample was divided into a coarsely milled (4 $\mathrm{mm}$ screen) sample for the in situ degradability determination and a finely milled sample ( $1 \mathrm{~mm}$ screen) for the in vitro digestibility studies and chemical analyses. The coarse samples were stored in plastic bags while the fine samples were stored in capped bottles. All samples were stored in dark cabinets pending analyses.

The DM, nitrogen $(\mathrm{N})$, crude protein $(\mathrm{CP})$, ether extract $(\mathrm{EE})$ and ash levels were determined according to the AOAC (1995) methods. The neutral detergent fibre (NDF) was determined using the method of Robertson \& Van Soest (1981) and acid detergent fibre (ADF), acid detergent lignin (ADL) and acid detergent insoluble nitrogen (ADIN) according to the method of Goering \& Van Soest (1970).

The Acid Butanol assay for proanthocyanidins (Porter et al., 1986) was used to obtain the condensed tannin (CT) concentration of the samples. After wet digestion with a nitric-perchloric acid mixture, the calcium $(\mathrm{Ca})$, magnesium $(\mathrm{Mg})$, manganese $(\mathrm{Mn})$, copper $(\mathrm{Cu})$, cobalt $(\mathrm{Co})$, zinc $(\mathrm{Zn})$ and iron $(\mathrm{Fe})$ concentrations were measured using atomic absorption spectrophotometry and the sodium (Na) and potassium $(\mathrm{K})$ concentrations using flame emission spectrophotometry. The photometric method using molybdovanadate was used to measure phosphorus (P) concentrations in the foliage (AOAC, 1990). After wet digestion, a hydride generator attached to an atomic absorption spectrophotometer (Perkin-Elmer 2380) was used in the assay of selenium (Se) in the samples. A peach leaf sample from the National Institute of Standards and Technology (NIST, US Department of Commerce, Gaithersburg, MD) was used as Standard Reference Material (SRM 1572) to verify the accuracy of the Se analysis.

The in vitro digestible organic matter (IVDOM) in the samples was determined using the method of Tilley \& Terry (1963), as modified by Engels \& Van der Merwe (1967). The in situ technique as standardized by the AFRC (1992) was followed to measure the rumen degradability of DM and N in the samples over a period of $48 \mathrm{~h}$. A lucerne hay sample with a known DM ruminal disappearance (internal laboratory standard) was included in each batch of incubations. Rumen cannulated sheep, fed a lucerne hay diet, were used in the in situ study and to supply the inoculum for the in vitro digestibility study.

The DM- and N-disappearance percentages (indicative of the herbage degradation kinetics) with time were fitted, using to the iterative least squares method in a nonlinear procedure (NLIN, SAS, 1994), to an exponential equation (Ørskov \& McDonald, 1979):

where:

$$
\mathrm{p}=\mathrm{a}+\mathrm{b}\left[1-\exp ^{-\mathrm{ct}}\right]
$$
$\mathrm{p}=$ the percentage herbage DM or $\mathrm{N}$ degraded after time $\mathrm{t}(\mathrm{h})$;
$\mathrm{a}=$ washing losses, soluble or rapidly degradable $\mathrm{DM}$ or $\mathrm{N}$ fraction. This value is the intercept of the degradation curve at time $0 \mathrm{~h}$;
$\mathrm{b}=$ the insoluble but potentially fermentable $\mathrm{DM}$ or $\mathrm{N}$ fraction which will degrade with time;
$\mathrm{c}=\operatorname{rate}(/ \mathrm{h})$ at which $\mathrm{b}$ is degraded

The chemical composition and in vitro digestion data were subjected to the GLM procedure of SAS (1994). The level of significance was tested with the Fischer Test (Samuels, 1989). Unless otherwise indicated, significance was declared at $\mathrm{P}<0.05$.

\section{Results}

The chemical composition of the foliage from the different tree species is presented in Table 1 . The $\mathrm{CP}$ concentration ranged from 70 to $170 \mathrm{~g} / \mathrm{kg} \mathrm{DM}$, though very few samples contained $<100 \mathrm{~g} / \mathrm{kg} \mathrm{DM}$. Mean CP concentrations differed $(\mathrm{P}<0.05)$ between species, with the $C$. mopane being then highest at 141 $\mathrm{g} / \mathrm{kg}$ DM. A seasonal effect was observed only in C. apiculatum, where the CP concentration in winter was lower $(\mathrm{P}<0.05)$ than those in the other seasons. The NDF levels of the samples varied between 300 and 400 $\mathrm{g} / \mathrm{kg}$ DM with no evidence of any seasonal effect. Between species, NDF values differed $(\mathrm{P}<0.05)$. The NDF levels were the highest in C. molle and C. mopane compared to the other two species. The ADF levels varied between 211 and $360 \mathrm{~g} / \mathrm{kg}$ DM. In spring, the ADF concentration was lower $(\mathrm{P}<0.05)$ in 
Table 1 Mean chemical composition $(\mathrm{g} / \mathrm{kg} \mathrm{DM} \pm$ s.e.) of foliage of the different tree species

\begin{tabular}{|c|c|c|c|c|c|c|c|c|c|}
\hline Season & $\mathrm{n}$ & $\begin{array}{l}\text { Crude } \\
\text { ash }\end{array}$ & $\begin{array}{l}\text { Crude } \\
\text { Protein }\end{array}$ & $\begin{array}{c}\text { Neutral } \\
\text { detergent fibre }\end{array}$ & $\begin{array}{c}\text { Acid } \\
\text { detergent fibre }\end{array}$ & $\begin{array}{c}\text { Acid detergent } \\
\text { insoluble N }\end{array}$ & $\begin{array}{c}\text { Acid detergent } \\
\text { lignin }\end{array}$ & Ether extract & $\begin{array}{c}\text { Condensed } \\
\text { Tannin }^{1}\end{array}$ \\
\hline \multicolumn{10}{|c|}{ Combretum apiculatum (red bushwillow) } \\
\hline Winter & 8 & $51 \pm 3$ & $107 \pm 7^{\mathrm{a}}$ & $321 \pm 14$ & $261 \pm 6^{\mathrm{a}}$ & $1.8 \pm 0.10$ & $55 \pm 3^{\mathrm{a}}$ & $54 \pm 3^{\mathrm{a}}$ & $505 \pm 37^{\mathrm{a}}$ \\
\hline Autumn & 8 & $55 \pm 2$ & $119 \pm 6^{\mathrm{b}}$ & $326 \pm 11$ & $251 \pm 5^{\mathrm{a}}$ & $1.5 \pm 0.05$ & $52 \pm 2^{\mathrm{a}}$ & $40 \pm 2^{b}$ & $515 \pm 27^{\mathrm{a}}$ \\
\hline Spring & 8 & $53 \pm 3$ & $118 \pm 24^{\mathrm{b}}$ & $319 \pm 18$ & $211 \pm 8^{\mathrm{b}}$ & $1.4 \pm 0.11$ & $43 \pm 4^{\mathrm{a}}$ & $37 \pm 4^{\mathrm{b}}$ & $286 \pm 48^{\mathrm{b}}$ \\
\hline Summer & 8 & $54 \pm 8$ & $118 \pm 24^{\mathrm{b}}$ & $332 \pm 45$ & $253 \pm 20^{\mathrm{a}}$ & $2.0 \pm 0.25$ & $80 \pm 10^{\mathrm{b}}$ & $45 \pm 9^{\mathrm{ab}}$ & $305 \pm 120^{\mathrm{b}}$ \\
\hline Mean & & $54 \pm 1.5^{\mathrm{p}}$ & $122 \pm 5^{\mathrm{pr}}$ & $323 \pm 7.1^{p}$ & $247 \pm 4.8^{p}$ & $1.7 \pm 0.13^{p}$ & $52 \pm 2.4^{\mathrm{p}}$ & $44 \pm 6$ & $467 \pm 26^{\mathrm{p}}$ \\
\hline \multicolumn{10}{|c|}{ Combretum zeyheri (large-fruited bushwillow) } \\
\hline Winter & 7 & $40 \pm 4$ & $109 \pm 11$ & $353 \pm 14^{\mathrm{a}}$ & $312 \pm 8^{\mathrm{a}}$ & $1.5 \pm 0.16$ & $61 \pm 5$ & $41 \pm 3^{\mathrm{a}}$ & - \\
\hline Autumn & 8 & $41 \pm 3$ & $120 \pm 7$ & $372 \pm 10^{\mathrm{a}}$ & $306 \pm 6^{\mathrm{a}}$ & $1.7 \pm 0.12$ & $66 \pm 4$ & $26 \pm 2^{b}$ & $104 \pm 36^{\mathrm{a}}$ \\
\hline Spring & 7 & $38 \pm 5$ & $125 \pm 15$ & $318 \pm 19^{\mathrm{b}}$ & $292 \pm 12^{\mathrm{a}}$ & $1.9 \pm 0.20$ & $51 \pm 7$ & $17 \pm 5^{\mathrm{b}}$ & - \\
\hline Summer & 8 & $40 \pm 6$ & $77 \pm 17$ & $297 \pm 22^{b}$ & $230 \pm 14^{\mathrm{b}}$ & $1.2 \pm 0.21$ & $60 \pm 8$ & $35 \pm 6^{\mathrm{a}}$ & $196 \pm 84^{\mathrm{b}}$ \\
\hline Mean & & $42 \pm 1.6^{\mathrm{q}}$ & $114 \pm 5^{\mathrm{r}}$ & $350 \pm 7.6^{\mathrm{q}}$ & $302 \pm 5.1^{q}$ & $1.6 \pm 0.18^{p}$ & $62 \pm 2.5^{\mathrm{q}}$ & $30 \pm 6$ & $359 \pm 57^{\mathrm{p}}$ \\
\hline \multicolumn{10}{|c|}{ Combretum molle (velvet bushwillow) } \\
\hline Winter & 2 & $71 \pm 6$ & $85 \pm 10$ & $382 \pm 16$ & $356 \pm 19$ & $2.0 \pm 0.18$ & $79 \pm 9$ & $45 \pm 8$ & $334 \pm 149$ \\
\hline Autumn & 4 & $54 \pm 6$ & $102 \pm 10$ & $398 \pm 16$ & $347 \pm 19$ & $1.9 \pm 0.17$ & $75 \pm 9$ & $29 \pm 8$ & $312 \pm 149$ \\
\hline Spring & 2 & $73 \pm 7$ & $99 \pm 11$ & $409 \pm 19$ & $364 \pm 22$ & $2.1 \pm 0.22$ & $64 \pm 10$ & $19 \pm 10$ & $317 \pm 175$ \\
\hline Summer & 4 & $85 \pm 12$ & $69 \pm 20$ & $358 \pm 34$ & $352 \pm 39$ & $1.4 \pm 0.34$ & $76 \pm 19$ & $39 \pm 8$ & $354 \pm 129$ \\
\hline Mean & & $67 \pm 2.5^{\mathrm{r}}$ & $92 \pm 8^{\mathrm{q}}$ & $392 \pm 12.2^{r}$ & $355 \pm 8.2^{r}$ & $1.9 \pm 0.23^{\mathrm{p}}$ & $75 \pm 4.0^{r}$ & $33 \pm 9$ & $382 \pm 54^{\mathrm{p}}$ \\
\hline \multicolumn{10}{|c|}{ Colophospermum mopane (mopane) } \\
\hline Autumn & 3 & $53 \pm 2$ & $154 \pm 11$ & $361 \pm 21$ & $299 \pm 24$ & $3.3 \pm 0.06$ & $136 \pm 18$ & $43 \pm 8$ & $660 \pm 8$ \\
\hline Spring & 3 & $55 \pm 2$ & $169 \pm 11$ & $373 \pm 21$ & $302 \pm 24$ & $3.0 \pm 0.06$ & $134 \pm 18$ & $41 \pm 8$ & $643 \pm 8$ \\
\hline Summer & 4 & $42 \pm 2$ & $99 \pm 13$ & $399 \pm 26$ & $322 \pm 27$ & $3.1 \pm 0.10$ & $168 \pm 22$ & $44 \pm 9$ & $659 \pm 10$ \\
\hline Mean & & $50 \pm 3.6^{\mathrm{s}}$ & $141 \pm 12^{\mathrm{p}}$ & $380 \pm 17.2^{\mathrm{qr}}$ & $307 \pm 11.6^{\mathrm{q}}$ & $3.1 \pm 0.08^{q}$ & $146 \pm 5.7^{\mathrm{s}}$ & $43 \pm 9$ & $652 \pm 62^{q}$ \\
\hline
\end{tabular}

${ }^{\mathrm{a}, \mathrm{b}}$ Within columns and species, different superscripts indicate seasonal differences $(\mathrm{P}<0.05)$;

$\mathrm{p}, \mathrm{q}, \mathrm{r}, \mathrm{s}$ Different superscripts indicate differences $(\mathrm{P}<0.05)$ between species means;

${ }^{1} \mathrm{mg}$ STE/g - sorghum tannin equivalent 
C. apiculatum than in the other seasons, while C. zeyheri contained the lowest ADF levels in summer. The average percentage ADF in the NDF was $83.5 \%$. The ADIN and ADL concentrations did not show any seasonal differences within species though the $C$. mopane leaves contained higher $(\mathrm{P}<0.05)$ ADIN and ADL concentrations than the other species tested. The CT concentration varied quite substantially, though the $C$. mopane leaves were higher $(\mathrm{P}<0.05)$ over all seasons compared to the other species.

The IVDOM in the leaves (Table 2) ranged from $52.6 \%$ in $C$. mopane and $C$. zeyheri to $64.1 \%$ for $C$. apiculatum, with no differences $(\mathrm{P}>0.05)$ in digestibility between seasons. The rumen degradable characteristics of the Combretum species are presented in Table 3. The soluble DM fractions (a) were very similar at $c a .33 \%$ for all three samples, while the soluble $\mathrm{N}$ fractions were much lower than the soluble DM fractions within species. Total DM degradability in all three species was between 78 and $94 \%$ compared to $\mathrm{N}$ disappearances of between 47 and 60\%. A similar trend between DM and $\mathrm{N}$ degradability was observed when degradability was calculated according to outflow rates.

Table 2 Mean in vitro digestibility ( $\% \pm$ s.e.) of organic matter of the foliage of different tree species in different seasons

\begin{tabular}{lcccccc}
\hline \multicolumn{1}{c}{ Species } & Winter & Spring & Summer & Autumn & $\begin{array}{c}\text { Total } \\
\text { Mean }\end{array}$ & Significance \\
\hline Combretum apiculatum & $58.4 \pm 1.9$ & $60.2 \pm 0.5$ & $64.1 \pm 2.6$ & $62.7 \pm 6.4$ & 60.4 & NS \\
Combretum zeyheri & $54.1 \pm 1.3$ & $56.8 \pm 0.9$ & $55.2 \pm 1.8$ & $56.8 \pm 12$ & 55.9 & NS \\
Combretum molle & $56.9 \pm 2.2$ & $55.7 \pm 2.2$ & $55.5 \pm 2.5$ & $54.1 \pm 4.5$ & 55.9 & NS \\
Colophospermum mopane & --- & $54.3 \pm 0.5$ & $52.6 \pm 0.5$ & $53.4 \pm 0.6$ & 53.4 & NS \\
\hline
\end{tabular}

Table 3 Rumen degradability characteristics of dry matter and nitrogen of the foliage of Combretum species

\begin{tabular}{|c|c|c|c|c|c|c|c|}
\hline \multirow[b]{3}{*}{ Species } & \multicolumn{7}{|c|}{ Degradation parameters } \\
\hline & \multirow{2}{*}{$\begin{array}{c}\mathrm{a} \\
\%\end{array}$} & \multirow{2}{*}{$\begin{array}{c}\mathrm{b} \\
\%\end{array}$} & \multirow[b]{2}{*}{$\mathrm{c}$} & \multirow[b]{2}{*}{ PD } & \multicolumn{3}{|c|}{ Effective degradability (\%) } \\
\hline & & & & & $\mathrm{K}=0.02$ & $\mathrm{k}=0.05$ & $\mathrm{k}=0.08$ \\
\hline \multicolumn{8}{|l|}{ Dry matter } \\
\hline Combretum apiculatum ${ }^{1}$ & 34.9 & 58.9 & 0.045 & 93.8 & 75.8 & 62.9 & 56.8 \\
\hline Combretum zeyheri ${ }^{2}$ & 35.4 & 47.2 & 0.056 & 82.6 & 70.5 & 604 & 54.9 \\
\hline Combretum molle 3 & 33.1 & 45.2 & 0.073 & 78.3 & 68.7 & 59.9 & 54.7 \\
\hline \multicolumn{8}{|l|}{ Nitrogen } \\
\hline Combretum apiculatum ${ }^{1}$ & 4.0 & 43.6 & 0.072 & 47.1 & 37.8 & 29.4 & 24.5 \\
\hline Combretum zeyheri ${ }^{2}$ & 25.4 & 35.0 & 0.042 & 60.3 & 49.1 & 41.4 & 37.5 \\
\hline Combretum molle ${ }^{3}$ & 10.7 & 39.9 & 0.056 & 50.6 & 40.1 & 31.8 & 27.2 \\
\hline
\end{tabular}

${ }^{1} \mathrm{n}=20 ;{ }^{2} \mathrm{n}=12 ;{ }^{3} \mathrm{n}=10$;

$\mathrm{a}$ - soluble fraction; $\mathrm{b}$ - insoluble fermentable fraction; $\mathrm{c}$ - degradation rate constant of the $\mathrm{b}$ fraction; PD - extent of degradation $(\mathrm{a}+\mathrm{b})$;

The washing of the samples after collection had no significant effect on the ash or mineral concentrations in leaves. Therefore, within each sample, the mineral concentrations of washed and unwashed samples were pooled. Mean mineral concentrations in the foliage are presented in Table 4. The P concentration in all the species, except for $C$. apiculatum, was the highest $(\mathrm{P}<0.05)$ in the summer. The average $\mathrm{Ca}: \mathrm{P}$ ratio for all samples was $9.3: 1$. No consistent seasonal patterns could be observed in any of the other minerals. In fact, any significant differences between seasons were measured in only a few of the minerals, e.g. a low $(\mathrm{P}<0.05) \mathrm{Cu}$ concentration in $C$. apiculatum in summer compared to its $\mathrm{Cu}$ concentrations in autumn and winter. In this study plant material was collected over a relatively wide range of soil types and climatic conditions. Some species have typical habitats, e.g. the Combretum species are often found in rocky hills and C. mopane is found only in the dry northern regions of the Limpopo Province, where the samples were collected. Therefore, since the foliage from different species was not necessarily 
Table 4 Mean concentration ( \pm s.e.) of minerals in the foliage of different tree species during the different seasons

\begin{tabular}{|c|c|c|c|c|c|c|c|c|c|c|c|}
\hline & \multicolumn{5}{|c|}{ Macro-elements } & \multicolumn{6}{|c|}{ Micro-elements } \\
\hline & $\mathrm{Ca}$ & $\mathrm{P}$ & $\mathrm{K}$ & $\mathrm{Mg}$ & $\mathrm{Na}$ & $\mathrm{Cu}$ & $\mathrm{Co}$ & $\mathrm{Fe}$ & $\mathrm{Zn}$ & $\mathrm{Mn}$ & $\mathrm{Se}$ \\
\hline & \multicolumn{5}{|c|}{$\mathrm{g} / \mathrm{kg}$ dry matter (DM) } & \multicolumn{5}{|c|}{$\mathrm{mg} / \mathrm{kg} \mathrm{DM}$} & $\mu \mathrm{g} / \mathrm{kg} \mathrm{DM}$ \\
\hline \multicolumn{12}{|c|}{ Combretum apiculatum (red bushwillow) } \\
\hline Autumn & $8.9 \pm 2$ & $1.4 \pm 0.1^{\mathrm{b}}$ & $6.6 \pm 0.9$ & $3.8 \pm 0.3$ & $0.036 \pm 0.002$ & $39.0 \pm 17^{\mathrm{ab}}$ & $0.16 \pm 0.05$ & $377 \pm 31$ & $18 \pm 3$ & $169 \pm 40^{\mathrm{a}}$ & $68 \pm 16$ \\
\hline Winter & $9.1 \pm 1$ & $0.9 \pm 0.1^{\mathrm{a}}$ & $5.7 \pm 0.5$ & $3.0 \pm 0.2$ & $0.035 \pm 0.001$ & $66.0 \pm 11^{\mathrm{a}}$ & $0.18 \pm 0.03$ & $391 \pm 20$ & $23 \pm 2$ & $48 \pm 25^{\mathrm{b}}$ & $82 \pm 10$ \\
\hline Spring & $9.5 \pm 1$ & $1.1 \pm 0.1^{\mathrm{a}}$ & $6.8 \pm 0.04$ & $3.0 \pm 0.1$ & $0.040 \pm 0.003$ & $27.0 \pm 8^{\mathrm{b}}$ & $0.13 \pm 0.02$ & $389 \pm 11$ & $22 \pm 1$ & $92 \pm 18^{b}$ & $68 \pm 7$ \\
\hline Summer & $11.0 \pm 3$ & $1.0 \pm 0.3^{\mathrm{a}}$ & $5.7 \pm 1.6$ & $2.8 \pm 0.5$ & $0.043 \pm 0.007$ & $12.0 \pm 34^{\mathrm{b}}$ & $0.15 \pm 0.10$ & $399 \pm 63$ & $13 \pm 5$ & $29 \pm 81^{\mathrm{b}}$ & $46 \pm 32$ \\
\hline \multicolumn{12}{|c|}{ Combretum zeyheri (large-fruited bushwillow) } \\
\hline Autumn & $11.0 \pm 3$ & $1.0 \pm 0.3^{\mathrm{a}}$ & $5.7 \pm 1.6$ & $2.8 \pm 0.5$ & $0.036 \pm 0.003$ & $10.1 \pm 5$ & $0.1 \pm 0.1$ & $435 \pm 75$ & $65 \pm 25$ & $163 \pm 58^{\mathrm{a}}$ & $120 \pm 66$ \\
\hline Winter & $11.0 \pm 1$ & $0.9 \pm 0.1^{\mathrm{a}}$ & $6.7 \pm 0.5$ & $2.1 \pm 0.2$ & $0.040 \pm 0.002$ & $11.0 \pm 1.2$ & $0.11 \pm 0.03$ & $299 \pm 41$ & $41 \pm 9$ & $91 \pm 20^{\mathrm{a}}$ & $112 \pm 23$ \\
\hline Spring & $10.0 \pm 1$ & $1.1 \pm 0.1^{\mathrm{a}}$ & $6.9 \pm 0.4$ & $2.3 \pm 0.2$ & $0.037 \pm 0.004$ & $14.0 \pm 1.0$ & $0.1 \pm 0.02$ & $223 \pm 31$ & $44 \pm 6$ & $29 \pm 15^{\mathrm{b}}$ & $149 \pm 17$ \\
\hline Summer & $12.0 \pm 2$ & $1.5 \pm 0.2^{\mathrm{b}}$ & $7.1 \pm 0.8$ & $2.1 \pm 0.3$ & $0.046 \pm 0.008$ & $15.0 \pm 1.7$ & $0.1 \pm 0.04$ & $195 \pm 58$ & $23 \pm 12$ & $58 \pm 29^{\mathrm{a}}$ & $74 \pm 32$ \\
\hline \multicolumn{12}{|c|}{ Combretum molle (velvet bushwillow) } \\
\hline Autumn & $16.0 \pm 4$ & $0.8 \pm 0.2^{\mathrm{a}}$ & $6.9 \pm 1$ & $3.2 \pm 0.1$ & $0.041 \pm 0.002$ & $7.9 \pm 0.4^{\mathrm{a}}$ & $0.18 \pm 0.1^{\mathrm{a}}$ & $311 \pm 50$ & $37 \pm 13$ & $51 \pm 29$ & $159 \pm 35$ \\
\hline Winter & $8.4 \pm 5$ & $1.1 \pm 0.4^{\mathrm{ab}}$ & $6.9 \pm 1$ & $1.4 \pm 1.0$ & $0.041 \pm 0.002$ & $7.8 \pm 1.0^{\mathrm{a}}$ & $0.17 \pm 0.1^{\mathrm{a}}$ & $275 \pm 71$ & $38 \pm 19$ & $59 \pm 59$ & $107 \pm 74$ \\
\hline Spring & $10.0 \pm 3$ & $1.5 \pm 0.2^{\mathrm{b}}$ & $6.4 \pm 1$ & $3.2 \pm 0.1$ & $0.038 \pm 0.003$ & $9.2 \pm 0.4^{\mathrm{b}}$ & $0.16 \pm 0.1^{\mathrm{a}}$ & $235 \pm 71$ & $39 \pm 14$ & $111 \pm 29$ & $79 \pm 35$ \\
\hline Summer & $9.4 \pm 4$ & $1.7 \pm 0.3^{\mathrm{b}}$ & $6.5 \pm 1$ & $1.4 \pm 0.1$ & $0.033 \pm 0.004$ & $9.1 \pm 1.0^{\mathrm{b}}$ & $0.69 \pm 0.1^{\mathrm{b}}$ & $234 \pm 71$ & $17 \pm 19$ & $134 \pm 40$ & $92 \pm 49$ \\
\hline \multicolumn{12}{|c|}{ Colophospermum mopane (mopane) } \\
\hline Autumn & $7.9 \pm 2^{b}$ & $0.8 \pm 0.2^{\mathrm{b}}$ & $7.8 \pm 1$ & $1.7 \pm 1.0^{\mathrm{b}}$ & $0.037 \pm 0.01$ & $12.0 \pm 2.4$ & $0.25 \pm 0.2$ & $207 \pm 13$ & $27 \pm 3$ & $112 \pm 39$ & $149 \pm 35^{\mathrm{b}}$ \\
\hline Spring & $11.2 \pm 2^{\mathrm{a}}$ & $1.4 \pm 0.2^{\mathrm{b}}$ & $1.2 \pm 1$ & $2.8 \pm 0.2^{\mathrm{a}}$ & $0.052 \pm 0.01$ & $11.0 \pm 1.7$ & $0.12 \pm 0.1$ & $169 \pm 12$ & $15 \pm 3$ & $102 \pm 28$ & $76 \pm 25^{\mathrm{a}}$ \\
\hline Summer & $9.1 \pm 2^{\mathrm{b}}$ & $2.1 \pm 1.0^{\mathrm{a}}$ & $6.8 \pm 1$ & $1.9 \pm 0.3^{\mathrm{b}}$ & $0.060 \pm 0.01$ & $15.0 \pm 2.0$ & $0.36 \pm 0.1$ & $176 \pm 11$ & $20 \pm 3$ & $166 \pm 34$ & $57 \pm 31^{\mathrm{a}}$ \\
\hline
\end{tabular}

${ }^{\mathrm{a}, \mathrm{b}} \mathrm{W}$ ithin columns and species different superscripts indicate seasonal differences $(\mathrm{P}<0.05)$ 
collected at the same location, a comparison in mineral concentration between tree species was considered largely meaningless, except if a species would display a distinct difference in the mineral concentration, which would have indicated that the plants could be a mineral accumulator. In general, the mineral concentrations were very similar, except for high concentrations of $\mathrm{Cu}$ in autumn and winter in $C$. apiculatum compared to the other species.

\section{Discussion}

The CP concentration of the foliage of the four species analysed, varied between approximately 70 and $170 \mathrm{~g} / \mathrm{kg}$ DM. This is towards the lower range of protein concentrations reported for the foliage of browse plant species (Rittner \& Reed, 1992; Apori et al., 1998; Larbi et al., 1998; Sawe et al., 1998; El hassan et al., 2000), especially lower than the CP levels in legume fodder trees and shrubs (Topps, 1992). In the present study, the CP levels of C. apiculatum leaves were similar to those measured by Groenewald et al. (1967), Sauer (1983) and Balogun et al. (1998). The CP concentrations in the leaves of C. molle and C. zeyheri were lower than those reported by Sauer (1983) and Malinga et al. (1999), while those in C. mopane were higher than levels reported by Groenewald et al. (1967). Factors such as differences in climate, soil types, etc. could have contributed to these differences. Ghanaian browse plants (presumably nonleguminous) had CP levels of 180 and $260 \mathrm{~g} / \mathrm{kg}$ (Apori et al., 1998). Larbi et al. (1998) reported similar higher levels of CP in fodder trees and shrubs in the humid tropics, and El hassan et al. (2000) in multipurpose leguminous trees, than in the present study. The four species investigated were all deciduous and only green leaves on trees were collected. The composition of fallen leaves and pods was not measured, but this might have been valuable to provide information on their CP concentrations for application when grasses are dry. El hassan et al. (2000) concluded that the multipurpose leguminous trees that they had analysed, should be good protein supplements provided that they are degraded in the digestive tract and are non-toxic. However, Shayo \& Udén (1999) pointed out that, although most browse species had high CP levels, tannins, if present, would interfere with the digestibility of the proteins and that a large proportion of the CP could be bound to the cell walls. Consequently, they concluded that a measurement of the CP concentration of topical browse is not a reliable indication of available protein in the leaves.

The concentrations of NDF and ADF in the foliage of $C$. apiculatum and C. molle were similar to the values reported by Balogun et al. (1998) and Malinga et al. (1999) for the same species respectively, though the ADL concentration in the present study was higher than that reported by Balogun et al. (1998). The foliage of $C$. mopane exhibited higher ADL concentrations than that of the Combretum species. Ghanaian browse plants (Apori et al., 1998) and multipurpose fodder trees and shrubs in the humid tropics (Larbi et al., 1998) contained NDF and ADL levels in ranges similar to those observed in the present study. In general, the browse species analysed in this study and in the reported investigations had lower levels of NDF than a large variety of grass species quoted by Meissner \& Paulsmeier (1995), while ADF and ADL concentrations were within the same range of the grass species. However, although the detergent extraction techniques are used regularly when analysing foliage from trees and browse plants (Balogun et al., 1998; Kallah et al., 2000), Makkar et al. (1995) pointed out that these techniques are not suitable for tannin-rich forages. The concentration of CT measured in the present study is expressed in terms of a specific standard (Mokoboki et al., 2002), sorghum tannin equivalent in this study, and not as the concentration in the dry material. This makes it difficult to interpret the results. However, the foliage apparently contained relatively high levels of CT, which would probably interfere with the availability of protein in a ruminant and in the laboratory determination of the detergent fibres.

The IVDOM range of the plants in the present study (53 to 64\%) fell within the range of 36 to $69 \%$ in vitro DM digestibility observed for tropical browse plants (Sawe et al., 1998) and in vivo OM digestibilities in goats (Kibria et al., 1994). However, the IVDOM levels were markedly lower than the in situ DM degradation of the same plant material. The rumen DM degradation estimates of the species in this study were within the range of those of various forage plants evaluated by Kamatali et al. (1992) and Balogun et al. (1998). Khazaal et al. (1994) and Apori et al. (1998) pointed out that the in situ technique should be used with caution when estimating the nutritive value of feeds containing high levels of phenolics because the potential negative effect of phenolic compounds on rumen microbial fermentation is unlikely to be detected by in situ methods. In vitro methods such as IVDOM and gas production measurements are more reliable in detecting inhibitory compounds in feeds because these compounds are likely to affect the activity of rumen microbes in a closed system (Khazaal et al., 1994; Balogun et al., 1998; El hassan et al., 2000). However, the in situ DM degradation may reflect the potential of the foliage for species possessing the 
ability to detoxify tannins, such as goats and probably many game species (Van Soest, 1994). The rumen degradability of DM in the present study was substantially higher than that of N. Using Ghanaian browse plants, Apori et al. (1998) found that the $\mathrm{N}$ degradability was equal and even higher than the DM degradability. They concluded that the browse species they had evaluated, contained low concentrations of compounds that would inhibit $\mathrm{N}$ digestion.

In many investigations leaves from trees and shrubs are proclaimed as suitable supplements to graminaceous fodder and crop by-products containing low protein and fermentable energy levels (Sawe et al., 1998; El hassan et al., 2000). However, Blair (1989) pointed out that such a supplement should constitute less than $15 \%$ of total feed intake. Furthermore, the concentration of the nutrients required in a supplement, such as tree or shrub fodder, should be about five times that required for the complete feed. It is concluded that the foliage from the Combretum species and C. mopane analysed in the present study contained too low concentrations of $\mathrm{CP}$, the availability of which is probably further reduced by tannins, to be considered as possible $\mathrm{N}$ supplements to grasses. By feeding the foliage, it would probably substitute some of the grass and complement a protein deficiency in dry grass. However, these species grow mainly in the arid subtropical regions of southern Africa, the so-called sweetveld regions, where grass maintains a relatively high level of nutrition even when dry (Tainton et al., 1993). The foliage of the tested species would obviously be valuable fodder sources during periods of feed scarcity, e.g. during droughts and in overgrazed situations, but cannot be considered as supplements to grass for grazing herbivores. Degen et al. (1997) concluded that the two Acacia species they had tested were unsuitable as sole food sources for small ruminants because of low intakes and negative $\mathrm{N}$ balances.

The ash content of the foliage in the present study compared well with that of the same species analysed by Groenewald et al. (1967), but was much higher than the values reported by Sauer (1983). Many factors can influence the concentration of mineral elements in plants, e.g. the plant species, minerals in the soil and their availability to the plant, soil type and soil $\mathrm{pH}$, stage of growth, etc. (Underwood \& Suttle, 1999). These factors and conditions differed between the species tested in the present study and would affect comparisons with values within species reported in the literature. When interpreting the results it has to be kept in mind that browsers select from a variety of tree and bush species and would not consume the foliage of the tested species only (Owen-Smith et al., 1983; Sauer, 1983).

The rinsing of the green leaves did not affect the mineral composition of the leaves. The effect of dust contamination on mineral concentration of the leaves is likely to be more pronounced during dry seasons and would depend on the mineral content of the dust. Gummow et al. (1991) and Grobler (1999) measured high concentrations of $\mathrm{Cu}$ on plant material close to an open shaft copper mine. This was found to be largely due to $\mathrm{Cu}$ in the dust, which contaminated the vegetation. Where no $\mathrm{Cu}$ contamination occurred, the washing had minimal effect on the $\mathrm{Cu}$ concentration of plants (Grobler, 1999).

In two of the four species, the $\mathrm{P}$ concentration in the leaves was significantly higher $(\mathrm{P}<0.05)$ in summer than in the other seasons. Groenewald et al. (1967) did not find any seasonal trend in the P concentration of C. apiculatum and C. mopane leaves, while Ramírez et al. (2001) found that the mineral concentrations in shrub species in Mexico were generally higher in spring and summer than in the other seasons. No consistent seasonal pattern could be observed for any of the other minerals. In fact, in only a few of the minerals were any significant differences between seasons measured, e.g. the low $(\mathrm{P}<0.05) \mathrm{Cu}$ concentration in $C$. apiculatum leaves in summer compared to $\mathrm{Cu}$ concentrations in autumn and winter. Although differences between species were not compared statistically, the mineral concentrations were very similar, except for high concentrations of $\mathrm{Cu}$ in autumn and winter in C. apiculatum.

When comparing the mineral concentrations in the leaves of the trees studied with mineral requirements of cattle and sheep under maintenance feeding conditions (NRC, 1996; Underwood \& Suttle, 1999) it is evident that the $\mathrm{Ca}$ and $\mathrm{Mg}$ concentrations in all species investigated were well above maintenance requirements throughout the different seasons. The Ca concentrations were exceptionally high, while the $\mathrm{P}$ concentration in the leaves was marginally below requirements of growing beef cattle, which varies between 1.2 and $2.7 \mathrm{mg} \mathrm{P} / \mathrm{kg} \mathrm{DM}$ (NRC, 1996). This resulted in the high $\mathrm{Ca}: \mathrm{P}$ ratio of $9.3: 1$. The $C$. apiculatum and C. mopane analysed by Groenewald et al. (1967) contained approximately the same concentration of $\mathrm{P}$ as in our study. Due to higher $\mathrm{Ca}$ levels they measure an even wider $\mathrm{Ca}$ : $\mathrm{P}$ ratio than in the present study. Topps (1992) summarised the results of different studies on legume shrubs and trees in which wide Ca: P ratios of up to 21.3:1 were measured, and Ramírez et al. (2001) reported similar wide Ca : $\mathrm{P}$ ratios for browse species in Mexico. Ruminants can tolerate a relatively wide $\mathrm{Ca}: \mathrm{P}$ in the diet provided that the P intake is high (Underwood \& Suttle, 1999). Otherwise, the bioavailability of $P$ would be 
drastically reduced and a P deficiency could occur (Underwood \& Suttle, 1999). Analysing the nutritional quality of the browse selected by giraffe in the Serengeti National Park, Pellew (1984) concluded that giraffe might select plant material high in $\mathrm{P}$, but found that the $\mathrm{Ca}$ : $\mathrm{P}$ ratio was still much higher than what is recommended for grazing livestock. Earlier, Western (1971) and Wyatt (1971) reported the occurrence of osteophagia, a symptom of P deficiency, in giraffe in Kenya. Similarly, Koen et al. (1988) calculated from the feed consumed by elephants in the Addo, Knysna and Kruger parks in South Africa that their diets contained $\mathrm{Ca}: \mathrm{P}$ ratios of $>6.25: 1$.

The foliage of all four tree species was slightly deficient in Na for livestock throughout the year, in agreement with observations by Blair (1989) and Topps (1992), while K concentrations were within the levels of adequacy for cattle (NRC, 1996). The concentration of $\mathrm{Cu}, \mathrm{Mn}$ and $\mathrm{Co}$ in the plant material analysed (Table 4.4.), would meet the requirements of these minerals for ruminants. The Fe concentrations were well above requirements, but not present at toxic levels. The Se concentration in only C. apiculatum was lower than the requirements for herbivores (NRC, 1996). The concentration of $\mathrm{Zn}$ in the foliage varied, though it was within the range considered adequate for sheep and cattle, according to Underwood \& Suttle, (1999), but low, according to the NRC (1996). The Cu concentration in the C. mopane leaves in our study compared well with the concentrations of $7.5-15.5 \mathrm{mg} \mathrm{Cu} / \mathrm{kg}$ DM in C. mopane leaves collected by Grobler (1999) in their control area, where no $\mathrm{Cu}$ contamination due to $\mathrm{Cu}$ containing dust was expected.

\section{Conclusion}

It was concluded that, because of the relatively low CP concentrations of foliage of the three Combretum species and C. mopane and the possible depressing effect of tannin on CP availability, the foliage of these species would not be effective protein supplements for ruminants grazing poor quality grass. The high $\mathrm{Ca}$ : $\mathrm{P}$ ratio and the low $\mathrm{Na}$ concentration in the foliage suggested that browsers consuming relatively large quantities of the material would need additional $\mathrm{P}$ and $\mathrm{Na}$ sources to overcome possible deficiencies in $\mathrm{P}$ and $\mathrm{Na}$. This would be an important consideration where these products are fed to ruminants under controlled or confined situations.

\section{Acknowledgements}

The authors wish to express their appreciation to B. Spreeth, G. Smit and E. Snyman for laboratory assistance, D. Hattas of the University of Western Cape for doing the CT analyses and to R.J. Coertze, H. Groeneveld and M.J. van der Linde for assistance with the statistical analyses. This material is based upon work supported by the South African National Research foundation under grant number 2046855.

\section{References}

AFRC, 1992. Nutritive requirements of ruminants: Protein. Report 9, Nutr. Abstr. Rev. (Series B). 62, 787835.

AOAC, 1990. Official methods of analysis (15th ed.). Association of Official Analytical Chemists, Inc., Arlington, Virginia, USA.

AOAC, 1995. Official methods of analysis (16th ed.). Association of Official Analytical Chemists, Inc., Arlington, Virginia, USA.

Apori, S.O., Castro, F.B., Shand, W.J. \& Ørskov, E.R., 1998. Chemical composition, in sacco degradation and in vitro gas production of some Ghanaian browse plants. Anim. Feed Sci. Technol. 76, 129-137.

Balogun, R.O., Jones, R.J. \& Holmes, J.H.G., 1998. Digestibility of some tropical browse species varying in tannin content. Anim. Feed Sci. Technol., 76, 77-88.

Blair, G.J., 1989. The diversity and potential value of shrubs and tree fodders. In: Shrubs and Tree Fodders for Farm Animals. Ed. Devendra, C., Proc. Workshop Denpasar, Indonesia. pp. 2-11.

Degen, A.A., Blanke, A., Becker, K., Kam, M., Benjamin, R.W. \& Makkar, H.P.S., 1997. The nutritive value of Acacia saligna and Acacia salicina for goats and sheep. Anim. Sci. 64, 253-259.

El hassan, S.M., Lahlou Kassi, A., Newbold, C.J. \& Wallace, R.J., 2000. Chemical composition and degradation characteristics of foliage of some African multipurpose trees. Anim. Feed Sci. Technol. $86,27-37$.

Engels, E.A.N. \& Van der Merwe, F.J., 1967. Application of an in vitro technique to South African forages with special reference to the effect of certain factors on the result. S. Afr. J. Agric. Sci. 10, 983-995.

Goering, H.K. \& Van Soest, P.J., 1970. Forage fiber analysis (apparatus, reagents, procedures and 
some applications). U.S.D.A.-A.R.S. Agriculture Handbook no. 379, Government Printing Office, Washington, D.C.

Grobler, D.G., 1999. Copper poisoning in wild ruminants in the Kruger National Park: Geobotanical and environmental investigation. Onderstepoort J. Vet. Res. 66, 81-93.

Groenewald, J.W., Joubert, D.M. \& Tölken, H., 1967. The chemical composition of South African fodder plants. Proc. S. Afr. Soc. Anim. Prod. 6, 117-128.

Gummow, B., Botha, C.J., Basson, A.T. \& Bastianello, S.S., 1991. Copper toxicity in ruminants: Air pollution as a possible cause. Onderstepoort J. Vet. Res. 58, 33-39.

Kallah, M.S., Bale, J.O., Abdullahi, U.S., Muhammad, I.R. \& Lawal, R., 2000. Nutrient composition of native forbs of semi-arid and dry sub-humid savannas of Nigeria. Anim. Feed Sci. Technol. 84, 137145.

Kamatali, P., Teller, M., Vanbelle, M., Collignon, G. \& Foulon, M., 1992. In situ degradability of organic matter, crude protein and cell wall of various tree forages. Anim. Prod. 55, 29-34.

Khazaal, K., Boza, J. \& Ørskov, E.R., 1994. Assessment of phenolics-related antinutritive effects in Mediterranean browse: A comparison between the use of the in vitro gas production technique with or without insoluble polyvinylpolypyrrolidone or nylon bags. Anim. Feed Sci. Technol. 49, 133-149.

Kibria, S.S., Nahar, T.N. \& Mia, M.M., 1994. Tree leaves as alternative feed resource for Black Bengal goats under stall-fed conditions. Small Rumin. Res. 13, 217-222.

Koen, J.H., Hall-Martin, A.J. \& Erasmus, T., 1988. Macro nutrients in plants available to the Knysna, Addo, and Kruger National Park elephants. S. Afr. J. Wildl. Res. 18, 69-71.

Larbi, A., Smith, J.W., Kurdi, I.O., Adekunle, I.O., Raji, A.M. \& Ladipo, D.O., 1998. Chemical composition, rumen degradation, and gas production characteristics of some multipurpose fodder trees and shrubs during wet and dry seasons in the humid tropics. Anim. Feed Sci. Technol. 72, 81-96.

Makkar, H.P.S., Borowy, N.K., Becker, K. \& Degen, A., 1995. Some problems in fiber determination of a tannin-rich forage (Acacia saligna leaves) and their implication in in vivo studies. Anim. Feed Sci. Technol. 55, 67-76.

Malinga, N., Wilson, V.J. \& Ndlovu, L.R., 1999. Content of phenolics and fibre did not influence wet season choice of tree species in duikers under captivity. S. Afr. J. Anim. Sci. (ISRP supplement) 29, 19-21.

Meissner, H.H. \& Paulsmeier, D.V., 1995. Plant composition constituents affecting between-plant and animal species prediction of forage intake. J. Anim. Sci. 73, 2447-2457.

Mokoboki, H.K., Ndlovu, L.R. \& Ayisi, K.K., 2002 Chemical and physical parameters of forage legume species introduced in the Capricorn region of Limpopo Province, South Africa. S. Afr. J. Anim. Sci. $32,247-255$.

NRC, 1996. Nutrient requirements of beef cattle (7th ed.). National Academy Press, Washington DC.

Ørskov, E.R. \& McDonald, I., 1979. The estimation of protein degradability in the rumen from incubation measurements weighted according to rate of passage. J. Agric. Sci., Camb. 92, 499-503.

Owen-Smith, N., Cooper, S.M. \& Novellie, P.A., 1983. Aspects of the feeding of a browsing ruminant: the kudu. S. Afr. J. Anim. Sci. 13, 35-38.

Pellew, R.A., 1984. The feeding ecology of a selective browser, the giraffe (Giraffa camelopardalis tippelskirchi). J. Zool. Lond. 202, 57-81.

Porter, L.J., Hristich, L.N. \& Chan, B.G., 1986. The conversion of procyanidins and prodelphinidins to cyaniding and delphinidin. Phytochem. 25, 223-230.

Ramírez, R.G., 1998. Nutrient digestion and nitrogen utilization by goats fed native shrubs Celtis pallida, Leucophullum texanum and Porlieria angustifolia. Small Rumin. Res. 28, 47-51.

Ramírez, R.G., Haenlein, G.F.W. \& Nunez-Gonzalez, M.A., 2001. Seasonal variation of macro and trace mineral contents in 14 browse species that grow in northeastern Mexico. Small Rumin. Res. 39, 153-159.

Rittner, U. \& Reed, J.D., 1992. Phenolics and in-vitro degradability of protein and fibre in West African browse. J. Sci. Food Agric. 58, 21-28.

Robertson, J.B. \& Van Soest, P.J., 1981. The detergent system of analysis and its application to human foods. In: The Analysis of Dietary Fiber in Food. Eds. James, W.P.T. \& Theander, O., Marcel Dekker, New York. pp. 123-158.

Samuels, M.L., 1989. Statistics for the Life Sciences. Collier Macmillan Publishers, London.

SAS, 1994. Statistical Analysis Systems user's guide, Version 6. SAS Institute, Inc., Cary, New Carolina. USA. 
Sauer, J.J.C., 1983. A comparison between Acacia and Combretum leaves utilized by giraffe. S. Afr. J. Anim. Sci. 13, 43-44.

Sawe, J.J., Tuitoek, J.K. \& Ottaro, J.M., 1998. Evaluation of common tree leaves or pods as supplements for goats on range area of Kenya. Small Rumin. Res. 28, 31-37.

Shayo, C.M. \& Udén, P., 1999. Nutritional uniformity of crude protein fractions in some tropical browse plants estimated by two in vitro methods. Anim. Feed Sci. Technol. 78, 141-151.

Tainton, N.M., Hardy, M.B., Aucamp, A.J. \& Danckwerts, J.E., 1993. The range environment. Ch 3, In: Livestock Production Systems: Principles and Practice. Eds. Maree, C. \& Casey, N.H., AgriDevelopment Foundation, Pretoria.

Tilley, J.M.A. \& Terry, R.A., 1963. A two-stage technique for the in vitro digestion of forage crops. J. Br. Grassl. Soc. 18, 104-111.

Topps, J.H., 1992. Potential, composition and use of legume shrubs and trees as fodders for livestock in the tropics. J. Agric. Sci., Camb. 118, 1-8.

Underwood, E.J. \& Suttle, N.F., 1999. The Mineral Nutrition of Livestock. (3rd ed.). CABI Publ. Oxon, UK.

Van Soest, P.J., 1994. Nutritional Ecology of the Ruminant, (2nd ed.). Cornell University Press. Ithaca, NY, $476 \mathrm{p}$.

Western, D., 1971. Giraffe chewing a Grant's gazelle carcass. E. Afr. Wildl. J. 9, 157-158.

Wyatt, J.R., 1971. Osteophagia in Masai Giraffe. E. Afr. Wildl. J. 9, 158. 